Nadwa | Jurnal Pendidikan Islam

Vol. 12 Nomor 1 Tahun 2018

Accredited by Ristekdikti based on Decree No. 51/E/KPT/2017

\title{
Transformation Of Pesantren Traditions In Face The Globalization Era
}

\author{
A. Suradi \\ IAIN Bengkulu, Indonesia \\ suradi@iainbengkulu.ac.id
}

\begin{abstract}
The phenomenon of Pesantren has been adopting common knowledge but still retaining the teaching classic books are attempts to forward the main purpose of the institution, namely education candidates clerics (ulama). In an effort to improve the quality of education, In an effort to improve the quality of education in the global era, the pesantren needs to do the transformation. Research method using library research. Result of research indicate there are three things that should be done by pesantren in doing transformation include First.Pesantren must have practical purposes that producing a generation of Islam is not only a smart serve smart vertically but also horizontally. Second: Pesantren must have ideological purposes it should be pesantren as main pillars of the formation of aqidah who ruled the General Science. Third : Pesantren make changes to the format, shape, orientation and method of education with no change the vision, mission and spirit of boarding, but the change only on the outside only, while on the side in the still retained
\end{abstract}

Keywords: Transformation; Pesantren ;Traditions; global era

\begin{abstract}
Abstrak
Fenomena Pesantren telah mengadopsi pengetahuan umum tetapi tetap mempertahankan pengajaran buku-buku klasik adalah upaya untuk meneruskan tujuan utama dari lembaga, yaitu untuk mendidik para kandidat ulama. Dalam upaya melakukan peningkatan kualitas pendidikan di era global, maka pesantren perlu melakukan transformasi. Metode penellitian menggunakan library research. Hasil penelitian menunjukkan ada tiga hal yang seharusnya dilakukan oleh pesantren dalam melakukan transformasi meliputi : Pertama. Pesantren harus memiliki tujuan praktis yang menghasilkan satu generasi Islam tidak hanya pintar melayani secara vertikal tetapi juga secara horizontal. Kedua: Pesantren harus memiliki tujuan ideologis, seharusnya pesantren sebagai pilar utama pembentukan aqidah yang menguasai Ilmu Pengetahuan Umum; ketiga: Pesantren melakukan perubahan pada format, bentuk, orientasi dan metode pendidikan tanpa mengubah visi, misi dan semangat pesantren, tetapi perubahan hanya di luar saja, sementara di sisi dalam masih dipertahankan
\end{abstract}

Keywords: Transformsi; pesantren; tradisi; era global; 


\section{Introduction}

In General; Pesantren can be distinguished to the pesantren of khalafiyah and salafi. The teaching system used classical methods. 1 This method is known as the sorogan or the individual service (Individual Learning Process); and the wetonan (Group); namely, the santri form halaqah and kyai were in the middle of explaining religious material is delivered, without a class level and a rigorous curriculum; and separate group of students based on gender.2

As a result, Salafi religious schools got the stigma as the institution out of date, conservative, exclusive and estranged. Today the Pesantren faced with many challenges, including the modernization of Islamic education. In many ways, the institutional system and the pesantren have been modernized and adapted to the demands of development, particularly in the institutional aspects that will automatically affect the curriculum. Furthermore, the question that arises is whether the Pesantren in determining the curriculum must be fused on the demands of the present era, or, he should defend it. How is alternative of pesantren curriculum format in the future?

How to organize the curriculum of religious schools in an attempt to elucidate the progress of thought and academic thought. This situation of pesantren curriculum needs to be a review. Zuhri said: "therefore, it must be intelligent efforts required to reconstruct Pesantren education system by formulating educational curriculum in an comprehensive (kaffah) education system ".3

1 Yasmadi, Modernisasi Pesantren : Kritik Nurcholis Madjid Terhadap Pendidikan Islam Tradisional, (Jakarta: Ciputat Press, 2002), Vol. I, page. 7071

2 Yasmadi, Modernisasi Pesantren: Kritik Nurcholis Madjid Terhadap Pendidikan Islam Tradisional, (Jakarta: Ciputat Press, 2002), Vol. I, page. 7071

3Saefuddin Zuhri, Pendidikan Pesantren di Persimpangan Jalan. Dalam Marzuki Wahid dkk. (Ed). Pesantren Masa Depan, Wacana Transformasi dan Pemberdayaan Pesantren, (Bandung: Pustaka Hidayah, 1999) page. 205 
The flow of globalization raises a great many changes from all aspects of life. These changes can not be avoided due to sophisticated increasing science and technology. 4 pesantrens should be able to fortify Islamic education itself. Thus, pesantren should not only keep religious science but also receiving a globalization without having to forget the principles in Islam to gain the happiness of the world hereafter.

\section{Definition of Pesantren}

The pesantren is institution of Islamic education where students live together in a complex and studied under the guidance of a teacher or kyai. 5 Pesantren is lack understood by people outside their environment, even though it has been present since hundreds of years ago. There is no historical record about when educational institutions of Islam first appeared in Indonesia. The institutional forms of the Pesantren as it is known now, grow around the end of the 19th century. 6

This Pesantren institution emerged as a respond of the Islamic community's traditional to get religious education. The institution has provided tremendous value investment in the life of society, the State and religion in Indonesia until now. Wahid said that, Pesantren is an Islamic educational that able to shaping the mindset and behavior students. 7 Pesantren differ with other educational institutions. The student or pupil live together with Kiai or teacher in a certain complex (funduq), that could grow a typical Pesantren characteristics, 8 such as:

1. The presence of a familiar relationship between students and kyai;

4 Nurcholish Madjid, Islam, Kemodernan, dan Keindonesiaan, (Bandung: Mizan, 2008), page. 72

5 Zamakhsyari Dhofier, Tradisi Pesantren Studi tentang Pandangan Hidup, (Jakarta: P3M, 2000), page. 50.

6 Ahmad Suedy, dan Hermawan, Sulistyo, Kyai dan Demokrasi Suatu Potret Pandangan Tentang Pluralisme, Toleransi, Persamaan Negara, Pemilu dan Partai Politik, (Jakarta: P3M, 2001), page. 1.

7 Abdurrahman Wahid, Pondok Pesantren Masa Depan, dalam Pesantren Masa Depan: Wacana Pemberdayaan dan Tansformasi Pesantren, (Jakarta: Pustaka Hidayah, 1999), page. 13

8 Zamakhsyari Dhofier, Tradisi Pesantren, page. 41. 
2. Students are obedient and submissive to their kyai;

3. The students live independently and simple;

4. The presence of the religious spirit in an atmosphere full of fraternal together;

5. The students trained and disciplined life (tirakat).

6. Frugal and simple

7. Dare to suffer to achieve one goal.

8. A good religious Life.9

\section{Characteristics Of Pesantren}

The pesantren has main character, 10 namely: first, established as part of the support of its people and on his own. Second, applying the students equality, did not distinguish the status and level of the wealth of his parents. Third, the Pesantren has a mission of eliminating ignorance.

In the history, the principal function of the Pesantren is to educate a religious scholar and expert. Until now the paradigm is still preserved, maintained and held by the founders and caregiver pesantren. However, over time, some Pesantrens have done a renewal with the development of other educational components; like math, natural science.

However, that Pesantren as Islamic institution remain with special characteristics: 11

1. Mosque. The mosque is an important element in Pesantren. Usually the mosque as a place of worship primarily the five daily prayers, also functioned as a place of teaching classical Islamic books. Its position as a centre of education. 12

2. The cottage or dormitories. According to Dhofier, there are three reasons why a pesantren have to provide dorm. First, the kyai fame and depth about Islamic knowledge attracts students from far away. Second, almost all pesantren located in villages where almost no housing to accommodate students. Third, there is an attitude of reciprocity where students assume kyai

9Nur Uhbiyati, Ilmu Pendidikan Islam. (Semarang: PT Pustaka Rizki Putra, 2013). page. 237

10 Departemen Agama, Pola Pembelajaran di Pesantren, page. 7

11 Zamakhsyari Dhofier, op cit, page. 17-18

12 Zamakhsyari Dhofier, Tradisi Pesantren ..., page. 49 
as his own and kyai considers students is as his responsibility. 13

3. Santri (Student). The term "Santri" has two connotations or understanding, the first; in connotated with those who obey and execute the run command of Islamic religion, or in other terminology is often referred to as "the orthodox Muslims. The distinguished in contrast with abangan people who are influenced by the values of Javanese culture, particularly the Islamic values derived from Hindu and Buddhist mysticism.14 The second; connotated with people who study in boarding institution. 15

4. The Religious teaching of classical religion books (kitab kuning). Kitab kuning is a book consists of two parts: the text of the material, the origin (the core) and syarh commentaries, explanatory text of material). In this kind of division, material is always placed at the edge (margin) to the right or left, while Sharh, because her much more long and is placed in the central part of kitab kuning, 16 with no symbol (syakal) so frequently among pesantrens termed "the bald". This then results in teaching methods that are textual with the methods sorogan and bandongan.

5. Kyai or Ustadz. kyai is pioneer, founding, managing, nurturing, lead and sometimes also as the sole proprietor of a pesantren and as a source of inspiration and as a moral support in his personal life.17 Therefore, the growth Pesantren is very dependent upon the personal of kyai capabilities, so be reasonable when we saw a lot of the Pesantren which broke up,

13 Zamakhsyari Dhofier, Tradisi Pesantren..., page. 46-47.

14 Bakhtiar Efendy, "Nilai-nilai Kaum Santri" dalam Dawan Raharjo (ed), Pergulatan Dunia pesantren Membangun dari Bawah, (Jakarata : LP3M, 1986). page. 37

15 Imam Bawani, Tradisionalisme dalam Pendidikan Islam..., page. 93 16Affandi Mochtar, "Tradisi Kitab Kuning: Sebuah Observasi Umum", dalam Marzuki Wahid, et.al. (penyunting), Pesantren Masa Depan Wacana Pemberdayaan dan Transformasi Pesantren, (Bandung : Pustaka Hidayah, 1999), page. 233

17 Abdurrahman Wahid, Menggerakkan Tradisi Esai-esai Pesantren, (Yogyakarta: Lkis, 2001), page. 6-7 
due to the death of its kyai left, while he has no offspring that can be continued leadership. 18

Pesantren is known as subculture, according to Abdurrahman Wahid, because there are three elements namely: (1) the pattern of leadership independent; (2) general reference books; (3) the system of values that is used is part of the wider community. 19 The education system in Pesantren, according to Abdul Mujib and Jusuf Mudzakir can be described as follows:

1. Using the traditional education system, with the presence of complete freedom in the process of analytical study, interactive relationship between occurrence of kiai and pupils.

2. The pattern of life in pesantren accentuates the spirit of democracy in practice solves the problem.

3. The students in studying at Pesantren are not solely looking for diplomas and degrees, like in the formal school system.

4. Culture Education in the drive to build and equip students to live simple, idealism, fraternity, equations, confident, togetherness and having the courage to be ready to live in the future.

5. In its history, graduated of pesantrens generally don't aspire to be master position in the government.20

Pesantren as institutions of Islam has several functions as explained Azyumardi Azra cited Sulthon Masyhud describes that Pesantren have three functions namely; the transfer of the Islamic sciences, Islamic traditions, maintenance and reproduction of the scholars. Pesantren also organises informal education in the form of the dinniyah madrasah teaches Islamic sciences.21

As traditional institutions, pesantrens have not a formula for educational purposes in detail, spelled out in an education complete system and consistently well planned. But in general, the purpose of pesantrens can be assumed to be as follows:

18 Imam Bawani, Tradisionalisme dalam Pendidikan Islam, page. 90.

19 Abdurrahman Wahid, Pondok Pesantren, page. 14

${ }_{20}$ Fatah Yasin, Dimensi-Dimensi Pendidikan Islam. Malang: UINMalang Press, 2008), page. 244

21 Sulthon Masyhud, et.al, Manajemen Pondok Pesantren, ed. Mundzier Suparta, Jakarta: Diva Pustaka, 2005 
1. The general objective, namely to guide students (santri) to become human personality who can afford the Islamic religion with science becoming an Islamic missionary in the surrounding communities.

2. Special purpose, that is to prepare the students to be pious person in religion taught by kyai is concerned as well as practice in the community. 22

The purpose of education Pesantren according to Zamakhsari Dhofir is "education is not merely to enrich the minds of pupils with explanations, but to improve the moral, train and heightens passion, respect the values the spiritual and humanitarian, teach attitudes and moral and honest tingkahlaku and prepare pupils to live simple and clean. It is created as keberagamaan basik, and the spirit of the Islamic mission of developing a responsi context the present religious and societal fields. 23

While Mastuhu suggested purposes of pesantren namely creating and developing the personality of the muslim faith and personality that is devoted to the Lord, akhlaq al karimah, beneficial to society or served to the community walking into them, or man of the society like Prophet Muhammad (follow the sunnah of the Prophet), able to stand on its own, free and fast in the personality, spread the religion of Islam or enforce an the triumph of Islam amongst the people (' izzul Islam wal Muslimeen). 24

\section{The Transformation of Pesantren Education in the face globalization Era}

The Pesantren, in general has experienced a shift from becouse of the impact of modernisation. Kiai of Pesantren is no longer the only source of learning. With a wide range of new learning resources, and the increasing dynamics of the communication between the pesantren education system and other systems, then the students learning from many sources. This

22 M.Arifin, Kapita Selekta Pendidikan (Umum dan Agama), (Semarang: Toha Putra, 1991), page. 110-111

23 Zamahkhsari Dhofir, Tradisi Pesantren, , page. 55.

24 Mastuhu, Dinamika Sistem Pendidikan Pesantren, Suatu Kajian Tentang Unsur Dan Nilai Sistem Pendidikan Pesantren, page. 55-56. 
situation causes a change in the relationship with Kyai santri. The identity of their relationship is more open and rational than before and the immediacy of personal relationships gradually fade away. 25

Similarly, there is a tendency that students need a degree and mastery of skills or areas of expertise, which can be delivered to master a particular life field. In modern times it is not enough only with with good moral, but also need to be equipped with the expertise or skills relevant to the needs of the workplace. The implications, is to change the propose of pesantren from educate prospective scholars, to the double, i.e. educate the students to be able to develop itself into "an religious intellectual and intellectual scholar (scholar, also knowing the knowledge of Islam) ". The core of all claims resulting from changes to the institutional modernization of education, in the world of contemporary Islamic Da'wah and education, not just change the base of socio-cultural and knowledge of students, but also induce on the Muslim Ummah as a whole.

Modernization in the world of contemporary Islamic Da'wah and education, is not just change the base of socio-cultural and knowledge of students, but also induce on the Muslim Ummah as a whole. In other words the boarding culture always undergoes a process of change in accordance with the dynamics of community supporters. Therefore, major changes were done by kyai against boarding institutions nowadays is the accumulation of the values of life endured throughout the boarding Historically, without leaving the ruh (spirit) or the most typical traditions.

Education Pesantren which is a blend of traditional and modern design to be an effective means in the form of modern humans. Nurcholish Madjid said that there are things more important in the Islamic education to resolve the issue of moral and ethical science modern. Nurcholis Madjid also expressed, that modernization is a rational, progressive and dynamic. He views that the modernization was a sense identical to the rationalization, thought patterns and reshuffle work old irrational

25 M Nasir Rofiq, Mencari Tipologi Format Pendidikan Ideal, Pondok Pesantren di Tengah Arus Perubahan, (Yogyakarta: Pustaka Pelajar, 2005), page. 55 
thought patterns and replace them with new work and the akliah (rational). 26

In many ways, the institutional system and the Pesantren have been modernized and adapted to the demands of development, particularly in the institutional aspects that will automatically affect the education system which refers to the institutional goals of the institution such. Furthermore, the question that arises is whether the Pesantren in determining the curriculum must be fused on the demands of the present era, or precisely, he should be able to defend it as the hallmark of a pesantren to creat a great ulama.

The pesantren as an educational institution shall make the change and renewal in order to produce a tough generation, a generation that knowledgeable with the power of the spirit's pesantren and firmness developing the knowledge that remain are sourced in the Qur'an and Hadith. In the times, pesantren is currently confronted with the currents of globalization and modernization which is characterized by fast pace of information and technology. Therefore, the pesantren had to make changes to the format, shape, orientation and method of education with a note not to change the vision, mission and spirit of boarding, but the change only on the outside only, while on the side in the still retained. 27

Thus, the pesantren with all its uniqueness still expected to be the underpinning of the development of the education system in Indonesia and the power of education to bring up the pillars supporting the leader of the nation's moral. Therefore, the current globalization presupposes the demands of professionalism in developing quality human resources. It is this reality that demands the presence of the management the management of the institution according challange of the times. The significance of professionalism education management becomes an inevitability

26Nurcholis Madjid, Bilik-Bilik, page. 172.

27 Abuddin Nata, Sejarah Pertumbuhan dan Perkembangan LembagaLembaga Islam di Indonesia, (Jakarta: Gramedia Widiasarana Indonesia, 2001), page. 155 . 
in the midst of the fierce currents of industrialization and the development of modern technology. 28

Thus in the era of globalization, according to the author of the pesantren educational institutions as Islam and rituals of Islam must have practical and ideological purposes. Practical purposes is producing a generation of Islam is not only a smart serve smart vertically, horizontally. Horizontal worship intelligence here is not only related to command regular worship as zakat, the victim, Aqiqoh, infaq and shodaqoh, but also pesantrens able to create generations who have the passion in the study the natural sciences and social sciences as well as continually consulted in solving problems for the benefit of the people. The second ideological purposes, it should be pesantren as main pillars of the formation of aqidah who ruled the General Science. This is what the authors refer to as a concrete step pesantren in the face of globalization era as a response to the phenomenon of Muslims in an increasingly global world lags behind in terms of General Science and technology. For example Muslims Health sciences mastering he will always hold the traditions of Islam, being Muslim character health expert, who bring up the symbols of Islam in a career in the world of health. If this situation can be happend then it goes according to the purpose of education pesantrens to create Islamic culture can be achieved.

\section{Conclusion}

The face of the current globalization boarding should perform the assimilation of modern science and technology, it is one way to pursue the failed Muslims in the era of globalization and modern. Therefore, major changes in pesantren should to transform in three things: First, Pesantren must have practical purposes that producing a generation of Islam is not only a smart serve smart vertically but also horizontally. Second, Pesantren must have ideological purposes it should be pesantren as main pillars of the formation of aqidah who ruled the General Science. Third, Pesantren make changes to the format, shape, orientation and method of education with no change the vision, mission and 
spirit of boarding, but the change only on the outside only, while on the side in the still retained

The most important is how humans can practise the teachings religious value in daily life, as well as the pesantren education emphasize the wholeness and alignment between the realm of their cognitive, affective and psikomotor. So, the pesantren can also be pushing the Islamic generations to improve the quality of the human profersional and the competitive power and the system also encourages communities to conduct human investment, i.e. improving the quality of human beings. A growing number of qualified human resources owned by a society will be even greater opportunities that the Community system of being able to win the global competition.

\section{Bibliography}

Arifin, M., 1991, Kapita Selekta Pendidikan (Umum dan Agama), Semarang: Toha Putra

Azra, Azyumardi, 2000, Pendidikan Islam Tradisi Dan Modernisasi Menuju milenium Baru, Ciputat: PT Logos Wacana ilmu.

Bawani, Imam, 1998, Tradisionalisme dalam Pendidikan Islam, Surabaya: al-Ikhlas.

Departemen Agama, 2001, Pola Pengembangan Pondok Pesantren, Jakarta: Ditjen Kelembagaan Agama Islam Proyek Peningkatan Pondok Pesantren

Dhofier, Zamakhsyari, 2000, Tradisi Pesantren Studi tentang Pandangan Hidup, Jakarta: P3M.

Madjid, Nurcholis, 1997, Bilik-Bilik Pesantren Sebuah Potret Perjalanan, Jakarta: Paramadina.

Madjid, Nurcholish, 2008, Islam, Kemodernan, dan Keindonesiaan, Bandung: Mizan.

Mastuhu, Dinamika Sistem Pendidikan Pesantren, Suatu Kajian Tentang Unsur Dan Nilai Sistem Pendidikan Pesantren, Jakarta.

Masyhud, Sulthon et.al, 2005, Manajemen Pondok Pesantren, ed. Mundzier Suparta, Jakarta: Diva Pustaka. 
Mochtar, Affandi, 1999,"Tradisi Kitab Kuning: Sebuah Observasi Umum", dalam Marzuki Wahid, (penyunting), Pesantren Masa Depan Wacana Pemberdayaan dan Transformasi Pesantren, Bandung : Pustaka Hidayah.

Nata, Abuddin, 2001, Sejarah Pertumbuhan dan Perkembangan Lembaga-Lembaga Pendidikan Islam di Indonesia, Jakarta: Grasindo.

Rofiq, M Nasir, 2005, Mencari Tipologi Format Pendidikan Ideal, Pondok Pesantren di Tengah Arus Perubahan, Yogyakarta: Pustaka Pelajar.

Suedy, Ahmad dan Hermawan, Sulistyo, 2001, Kyai dan Demokrasi Suatu Potret Pandangan Tentang Pluralisme, Toleransi, Persamaan Negara, Pemilu dan Partai Politik, Jakarta: P3M.

Wahid, Abdurrahman, 1999, Pondok Pesantren Masa Depan, dalam Pesantren Masa Depan: Wacana Pemberdayaan dan Tansformasi Pesantren, Jakarta: Pustaka Hidayah.

--------------,2001, Menggerakkan Tradisi Esai-esai Pesantren, Yogyakarta: Lkis.

Yasmadi, 2002, Modernisasi Pesantren : Kritik Nurcholis Madjid Terhadap Pendidikan Islam Tradisional, Jakarta: Ciputat Press.

Zuhri, Saefuddin, 1999, Pendidikan Pesantren di Persimpangan Jalan. Dalam Marzuki Wahid dkk. (Ed). Pesantren Masa Depan, Wacana Transformasi dan Pemberdayaan Pesantren, Bandung: Pustaka Hidayah. 